\title{
CHRONOLOGY OF THE URBAN EXPANSION OF KUMANOVO
}

\author{
DOI: http://dx.doi.org/10.18509/GBP.2019.68
}

UDC: $711.433-044.88(497.721)$

\author{
Maja Lazarevska ${ }^{1}$ \\ Blagoja Markoski ${ }^{2}$ \\ ${ }^{1}$ Ministry of Transport and Communications of the North Macedonia \\ ${ }^{2}$ University "St. Cyril and Methodius" Skopje, Faculty of Natural Sciences and Mathematics, \\ Institute of Geography, North Macedonia
}

\begin{abstract}
The phenomenon of spatial expansion and sprawling of cities in one particular territory is a condition that has greatly influenced the contemporary city and society, from the physical/spatial aspect, social, as well as the aspect of urban development.

The topic of this study is the genesis and the matrix of the spatial development of Kumanovo and determining the cause-effect factors and results.

The main thesis of the study suggests necessity for introducing a program-spatial matrix/paradigm in the development, so as to regulate the spatial expansion of the urban web. The program-spatial matrix is associated with the segment of planning, or the introduction of the normative structure.

The work methodology is based on comparative analysis of the changes from a spatialphysical and a planning point of view. Due to the specifications of the region concerned, this study, in methodological sense, starts with providing documentary grounds, based on methods of collecting, documenting and analyzing the information found.

The conclusion of this study encourages the need for introducing a normative structure in the spatial development planning of cities in order to improve the spatial quality, the economic dynamics and the social cohesion.

The results of the study analyses ought to provide a clearer representation of the relations between the urban planning (spatial and general) and the space as well as the consequences of their implementation, or non-implementation.
\end{abstract}

Keywords: spatial development, spatial expansion, urban development, pole, axis of influence

\section{INTRODUCTION}

The topic of this study is the city of Kumanovo, the center of a mesoregion, a pole with a great influence in the region, its geographical position in the region, or the spatial-physical context in the geographical surroundings, as a phenomenon with its own specific individual development. For better understanding of the issue, an analysis of the naturalgeographic, social-geographic and economic-geographic features of the space has been made. The spatial and urban city planning has been observed as a special segment. The city of Kumanovo is marked by nearly a hundred years of history of spatial planning. The spontaneous and non-regulated development of the urban web (taking place until 1923) from 1923 is replaced by a process of urban development and urban planning. The planning documents are the result of the inconsistent social-political conditions that existed in that particular moment, as well as of the position and the significance of Kumanovo in that particular territory. From 1923 until today four urban plans have been 
adopted, each of them covers the city integrally and define its development as such. The plans have different content and qualitative characteristics. They represent the atmosphere, the aspirations of the officials in charge and the actual relevant legislation. In this study, different planning treatments are separately discussed in relation to the adopted plans, their decision on the boundaries of the urban-planning area as well as the city boundaries. The goal is to analyze the process of spatial and urban expansion of Kumanovo, with a special emphasis on the cause-effect relationships arising from the physical conditions.

\section{NATURAL - GEOGRAPHIC CHARACTERISTCS}

The city of Kumanovo is located in the northeast planning region (Nomenclature of Territorial Units for Statistics - NUTS level 3), one of the eight non-administrative units - statistic regions which arouse by grouping the municipalities from lower rank in administrative units in the Republic of Macedonia. [2] This planning region covers an area of $2,310 \mathrm{~km} 2$ and has a population of 173,814 (or $9 \%$ of the population in the Republic of Macedonia). The region consists of the municipalities: Kratovo, Kriva Palanka, Kumanovo, Lipkovo, Rankovce and Staro Nagorichane. According to the population number and the 2002 census, Kumanovo is the largest municipality in Macedonia with 105,484 inhabitants. It is also the centre of the region. [5] [17]

An important element (which is a strong factor of influence in the spatial disposition of the city) for the population and the economic - functional development of Kumanovo is its geographical position where the traffic corridors 10 and 8 (the Vardar-Morava axis of development and the direction along the Kriva Reka towards Bulgaria) intersect. [9] The openness of the Kumanovo Valley to the Moravian Valley in the north, to the Vardar, i.e. the Skopje Valley, in the south and to the valley of the Kriva Reka towards Kriva Palanka contributes to the establishment of the connections.

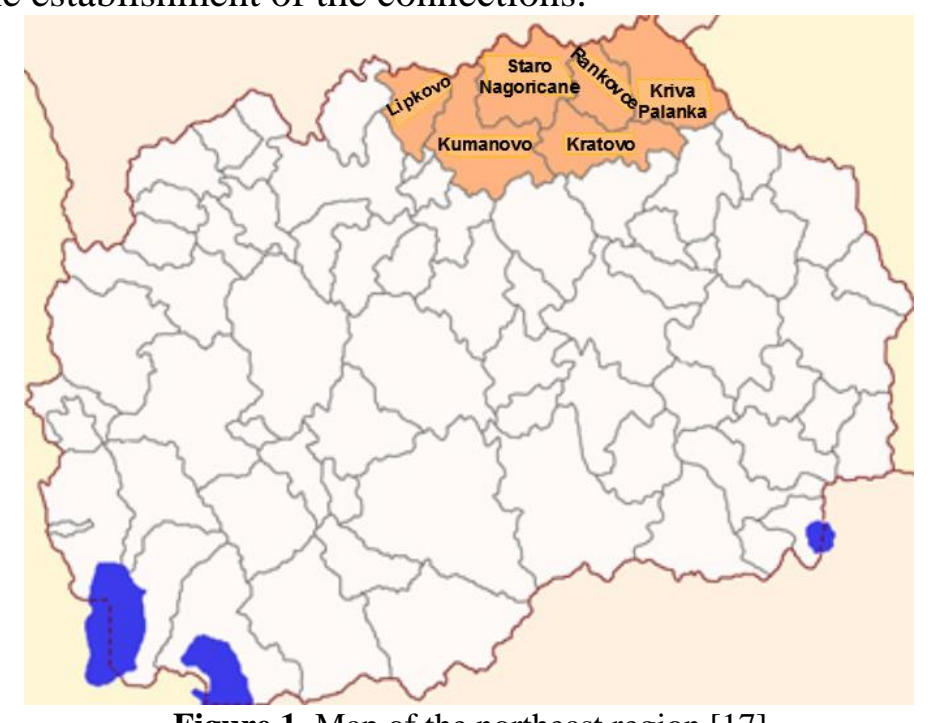

Figure 1. Map of the northeast region [17]

The territory of the municipality of Kumanovo is distinguished by a heterogeneous relief structure. Tectonically, its territory belongs to the Serbo-Macedonian zone. The Kumanovo Valley and the mountains of Skopska Crna Gora, Kozjak and Ruen are one of the most distinct relief forms in this region. However, the plain-hilly land at an elevation of about 300-700 m. dominates in the relief structure. The volcanic basaltic plateaus and 
the gorge-like parts of the Pchinja River downstream of the village of Pelince and the Beslimska Gorge are among the most characteristic relief forms of the region.

The area is seismically active, with frequent earthquakes measuring up to $7^{\circ} \mathrm{MCS}$. In the municipality area, there are reserves of metallic and non-metallic mineral resources that are in the process of exploitation.

The temperate continental climate dominates the lowlands of the Kumanovo Valley, while in the higher parts, the dominant climate is the continental climate. The average annual temperature in the lowlands is $12^{\circ}$ and in the mountainous regions it is $8^{\circ}$. In the area there is a disruptive pluviometric regime of precipitation and increased frequency of winds from the north and north-west directions.

From a hydrographic aspect, the waters in these terrains have low yielding properties. There are 311 springs registered, most of which have low yielding properties up to $11 /$ sec. The river network consists of the middle and lower reach of the Pchinja River, the Kumanovska River and the Kriva River, which belong completely to the Pchinja basin. Particularly important are the "Glaznja" and "Lipkovo" reservoirs built on the Lipkovska River. Groundwater is present in the Kumanovo Valley, some of which is manifested as thermomineral water. Areas with more pronounced erosive processes (I, II and III category) are also found in the region.

The area is characterized by a variety of vegetation species. Natural species are preserved in the peripheral parts. Forest complexes (mainly from oak and beech) as well as a large number of shrubs are preserved on the mountain of Skopska Crna Gora and partly on the mountain of Kozjak. Pastures occupy a large area, mostly in the hilly parts, and partially in the mountainous parts of Skopska Crna Gora.

The flat and hilly areas are characterized by favorable relief soil conditions for agricultural management. Lands of the higher-rank solvency classes (I, II and III) are present in the lowlands, while on the hilly and mountainous areas there are lands of the lower-rank solvency classes (IV, V, VI and VII).

The arable land in the municipality of Kumanovo covers an area of $556 \mathrm{~km} 2$ (55,600 ha), of which 6,794 ha are surfaces equipped with hydro-melioration systems. The forests cover an area of 31,679 ha, of which 23,429 ha are forests and 8,250 ha are barren land. In the development of the system of settlements in the period after the Second World War, the process of strong depopulation and deagrarization of the rural population, especially characteristic for the settlements in the hilly and mountainous regions, becomes explicit. This process caused an increased concentration of this population towards the municipal center of Kumanovo, so that, in the city, the processes of urban planning and organization are developed and realized.

The process of urbanization is intense with elements of discrepancy between the highly concentrated urbanization type and the possibilities of general social development. This causes inadequate urban planning and organization of the city of Kumanovo with great differences in the functional facilities of the settlements. There are occurrences of unregulated urban expansion of the city in the lowlands near the city and near the more significant roads. The urban conditions of these instances of urban expansion are inappropriately regulated or not regulated at all. In this context, the chronology of the urban expansion of the city of Kumanovo is presented below with all the advantages and disadvantages. [9] 


\section{CHRONOLOGY OF THE URBAN EXPANSION OF KUMANOVO}

The earliest data about Kumanovo as a village settlement date back to 1519, as part of the Nagorichane district of that time. It grew into a city settlement in the second half of the 16th century or the beginning of the 17th, when it became the administrative centre of the district, with typical Ottoman features. Until the 1920s, when the Moravia-Vardar Valley corridor was enhanced (railway and modern roads were built), Kumanovo developed spontaneously and unsystematically. [6] [11] [12] [18]

\section{Adopted urban plans}

The city's planning period began in the 1920s, following the liberation from the Ottoman rule. During this period, within a time frame of almost a hundred years, four urban plans (that cover the city as a whole) for Kumanovo have been adopted, as well as two legal acts that refer to the urban area of the city. They are:

- Regulation Plan from 1923;

- Decision no. 1894/1 dated 28.02.1959 of the former National Committee of the Kumanovo District;

- Proposal for expansion of the building land for the city of Kumanovo submitted by the Council for Communal Affairs and Urban Planning of Kumanovo and adopted by the Assembly of the Municipality of Kumanovo, with decision no. 5981/1 dated 24.07. 1968;

- Basic Urban Plan (BUP) from 1971;

- Basic Urban Plan - Amendments from 1986;

- General Urban Plan from 2002.

\section{Regulation Plan from 1923}

The first official planning document for the city of Kumanovo is the 1923 Regulation Plan. The plan was made in Belgrade by the architect Dusan Mirosavljevic, with an emphasized tendency to de-Ottomanize the structure of the city and was approved by the Minister of Construction of the Kingdom of SCS in 1923. Regarding the legislation, according to the periodization of Siljanoska [14], the plan belongs to the "period from 1914-1948: a period when the urban activity and the legislative material are established, through which an integral treatment of all aspects important for control of the spatialphysical development of the city is ensured ". When the plan was adopted, the city authorities began with activities for its implementation. It is especially important to emphasize the manner and seriousness with which they approached the realization of the city regulation, through an authorized person, the Russian architect Vladimir Apolonovich Antonov. He was in charge of performing all construction technical tasks. The plan itself had a direct, immediate application. This period marks the establishment of the outlines of the city's web, streets were traced and a large number of residential and public facilities were built. They became an integral part of the old city core. In this period, the city had about 15,000 inhabitants. In 1931, the Constructional Law, which is also applied in the implementation of the plan, was adopted. "The 1931 Law directs the urban activity towards the organization, construction, expansion and sanitation of cities, i.e. towards the physical aspects of the city development ... it provides a considerable degree of discipline in achieving the desired physiognomy of the city." [10] In 1933, the first cadastral record of the city was made and a census cadastre was established, whose regulation was formed on the basis of an orthogonal survey conducted in 1933-34 and 
partially on the basis of a classical census. Plans with scale 1: 500 were made for sections that underwent surveys. [1]

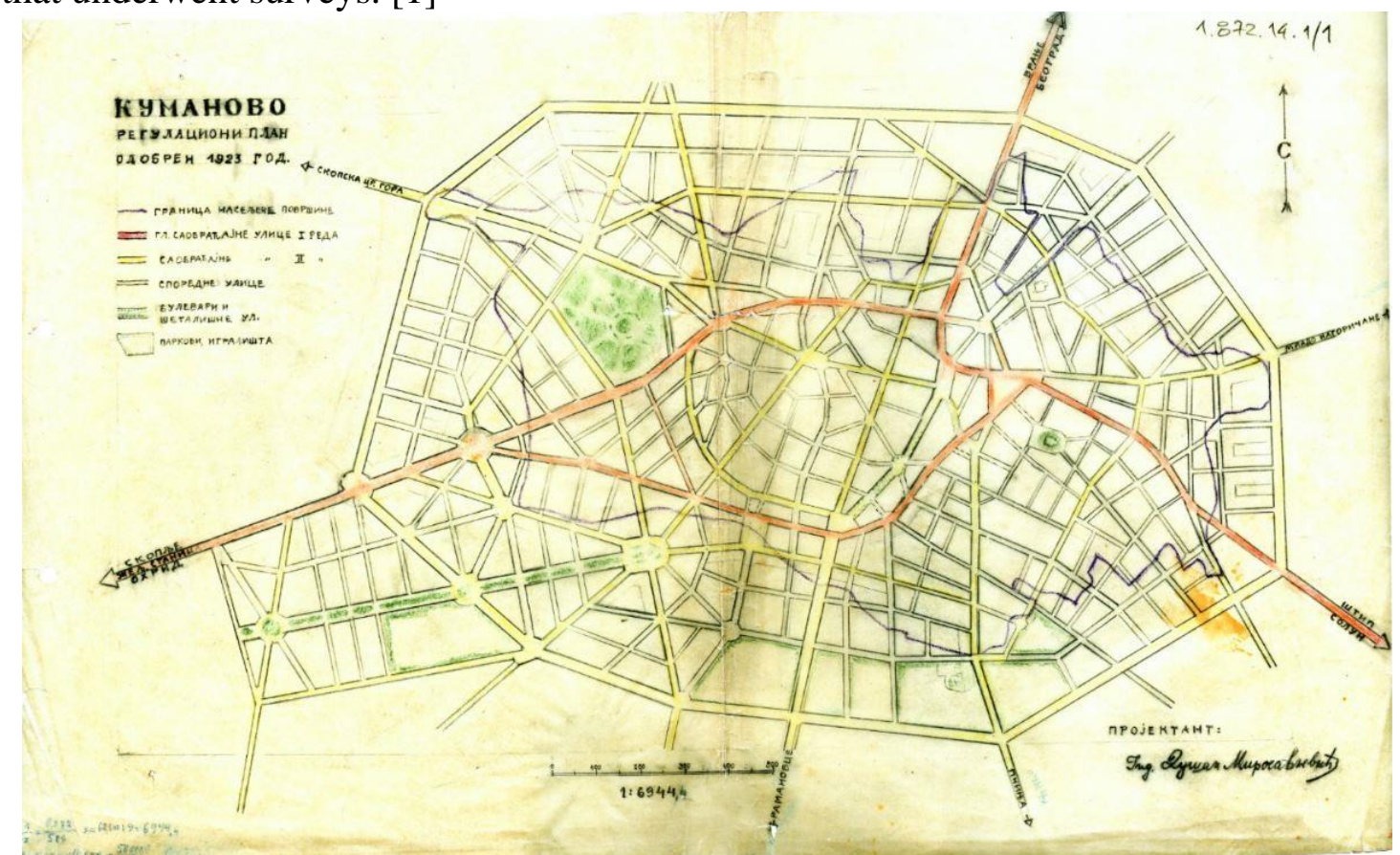

Figure 2. The 1923 Regulation Plan. Source: Municipality of Kumanovo [4]

From an administrative-territorial aspect, the city was the centre of the District (Provincial) Government until 1965, when the districts as secondary territorialadministrative units were abolished. The plan covers an urban area of 283.17 ha. [12] [18].

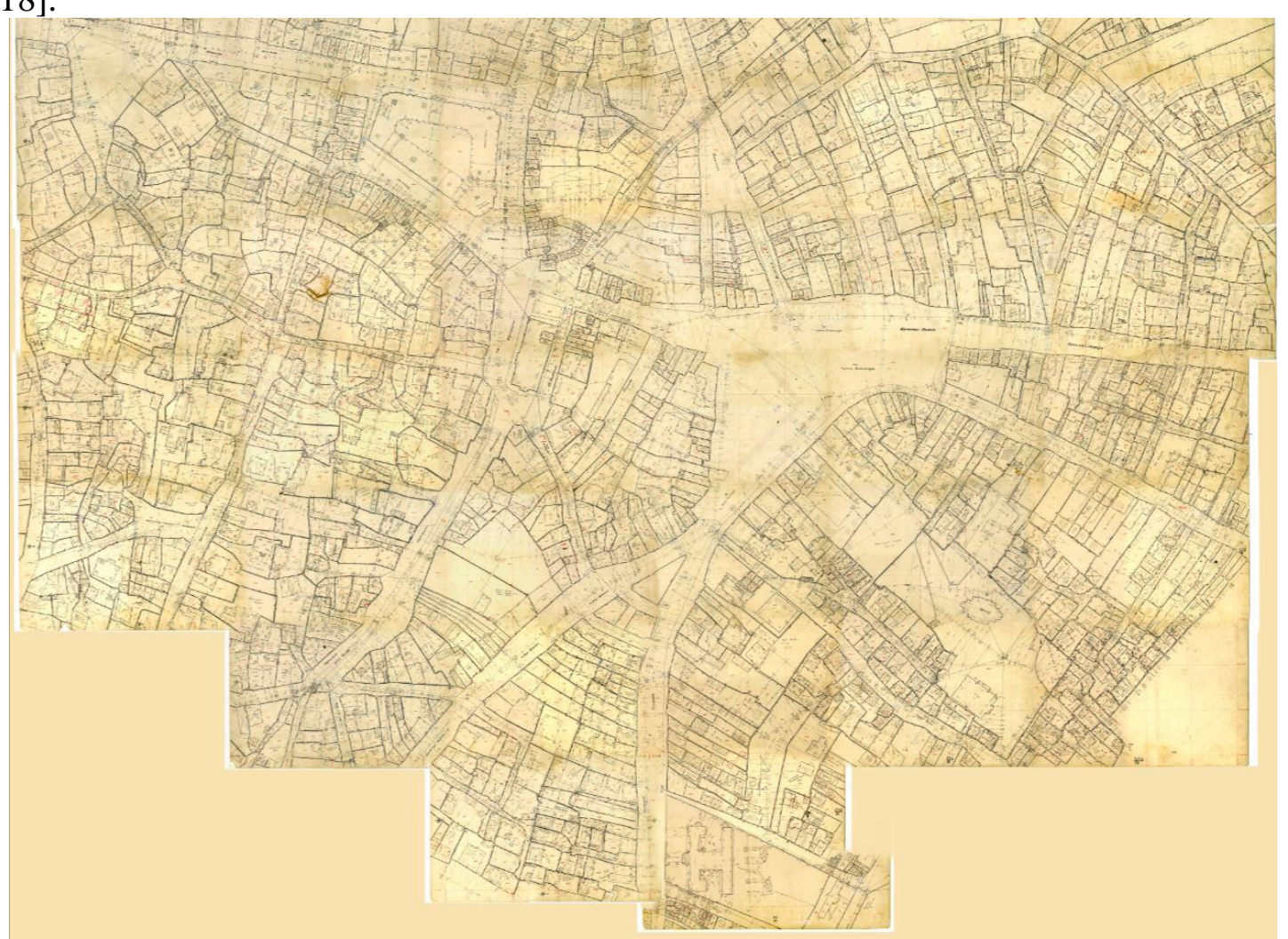

Figure 3. The 1923 Regulation Plan. Source: Municipality of Kumanovo [4] 


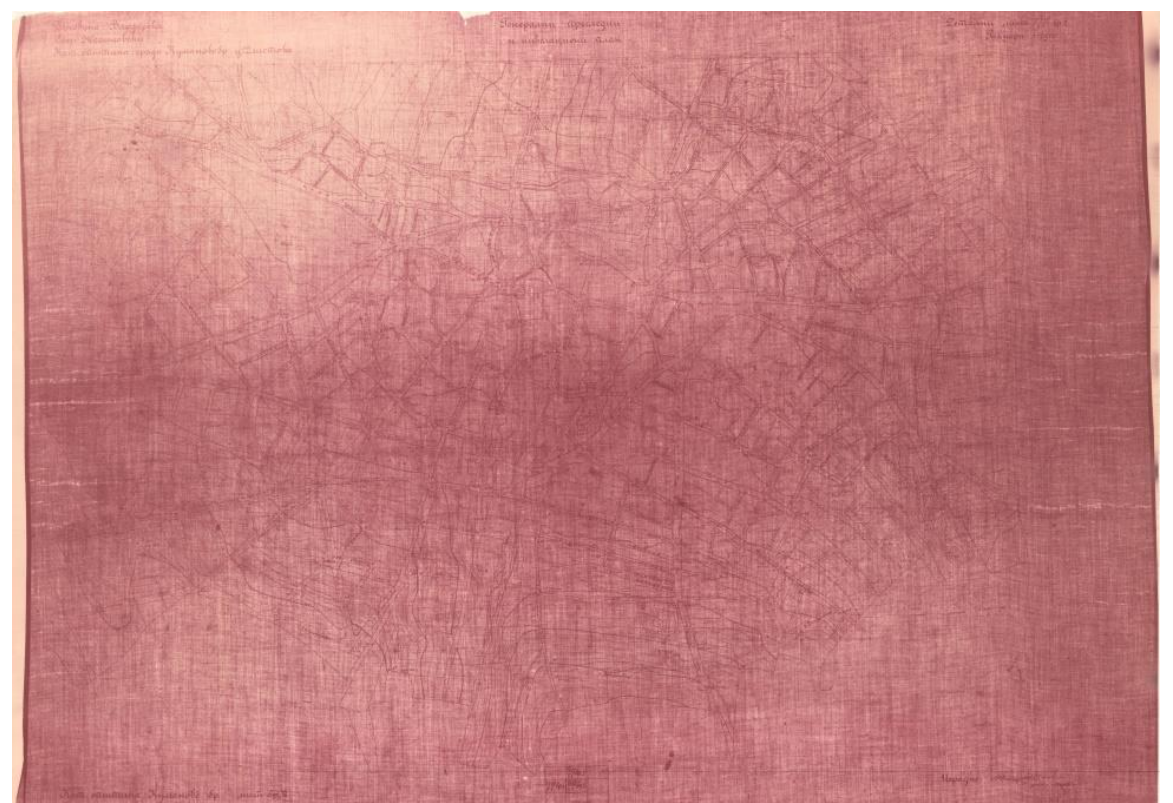

Figure 4. Cadastre plan from the recording in 1933. "General Review and Leveling Plan" 1: 2500 Source: Prostor Kumanovo

\subsection{Decision no. 1894/1 dated 28.02.1959 of the}

\section{former National Committee of the Kumanovo District}

The National Committee of the Kumanovo District with the Decision no. 1894/1 dated 28.02.1959 determines the boundaries of the city's building land. The boundaries of this construction land are taken from the geodetic foundations made on the basis of aerial photogrammetry in 1962, since on them the boundary of the building land is additionally drawn up, probably for the needs of the cadastre. The determination of the boundaries of the building land is taken from Antevski N. "Analyses for the Purpose of Legalization of Illegally Constructed Objects within and out of Building Land" [1]. In figure 5 the land is represented in blue. The area of the urban land determined by the Decision is about 516 ha.

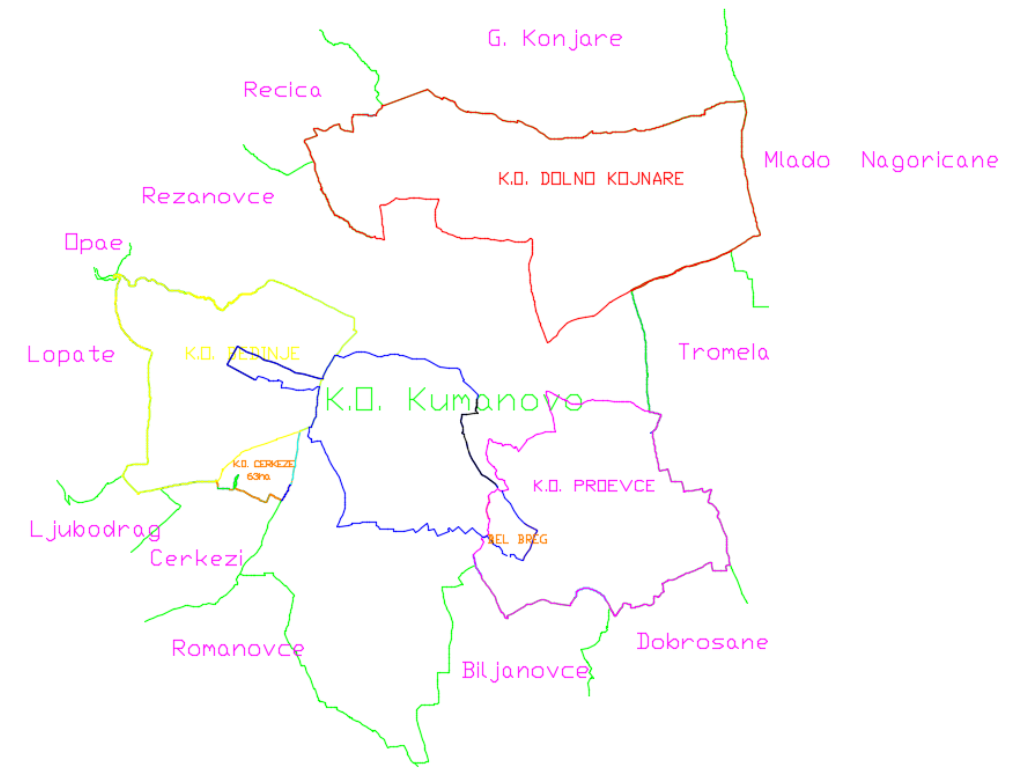

Figure 5. Building land in Kumanovo established with the Decision no. 1894/1 dated 28.02.1959 of the former National Committee of the Kumanovo District. Source: [1] 
Proposal for expansion of the building land for the city of Kumanovo, submitted by the Council for Communal Affairs and Urban Planning of Kumanovo, and adopted by the Assembly of the Municipality of Kumanovo, with decision no. 5981/1 dated 24.07. 1968

The next expansion of the boundaries of the city's building land was the result of the Proposal for expansion of the building land for the city of Kumanovo, adopted by the Assembly of the Municipality of Kumanovo, with decision no. 5981/1 dated 24.07. 1968. Antevski outlined the expansion based on the described boundaries towards the cadastral parcels that were then in use. The expansion of the boundaries partially borders on the existing building land, for the purpose of creating a constructional bare land which will meet the needs for construction. [1]

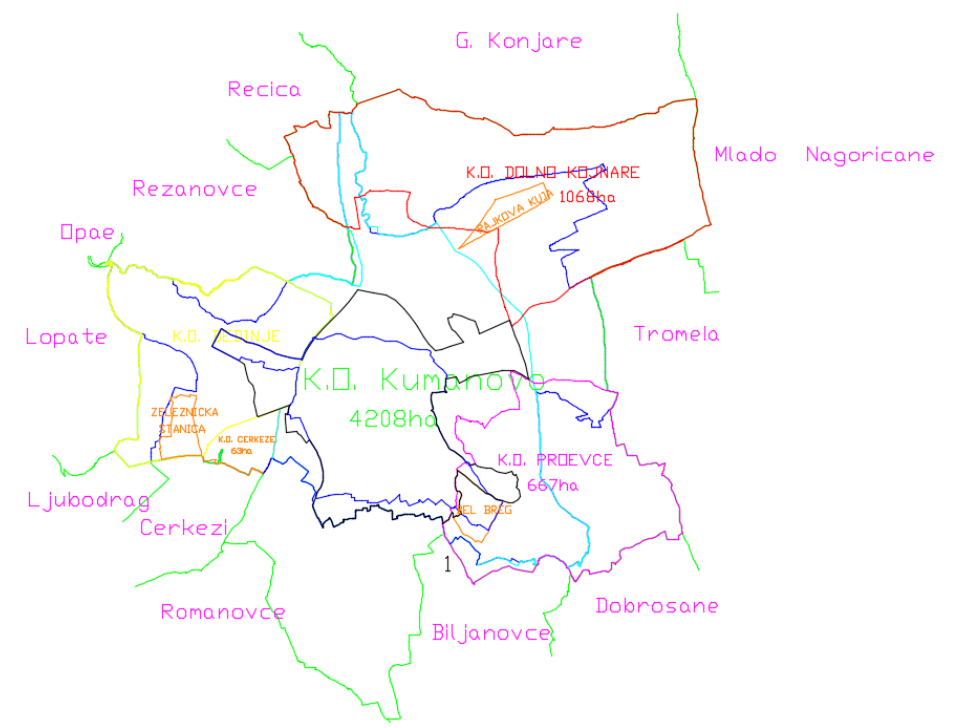

Figure 6. Building land for the city of Kumanovo in 1968. Source: [1]

\section{Basic Urban Plan (BUP) from 1971}

For the needs of the Basic Urban Plan for Kumanovo in 1968, the geodetic foundations of the city were developed and an urban study was conducted by the Institute for Urban Planning and Architecture of the City of Skopje (IUAS). Regarding the legislative framework, the plan was adopted in accordance with the 1953 Law on Urban Planning, which Siljanoska classifies in the "first generation" of urban laws [14]. The perceptions of the situation and the current development needs lead to the preparation of the Basic Urban Plan in 1971 by IUAS, Skopje. The plan is a conceptually developmental document with indirect application through further development with detailed urban plans. According to Korobar's classification, it belongs to the period of "further decentralization of society and the emphasized influence of world experiences." [10] The city had 46,363 inhabitants. The process of migration of the population from the rural areas to the city was distinctively noticeable. According to the census in 1961, the city's population was 30,845, and in 1981 it had 60,842 inhabitants (the third city in the Republic of Macedonia by number of inhabitants), which is an increase of about $25 \%$ over a period of one decade, or doubling over a period of two decades. This phenomenon produces problems and collisions in the organization and the utilization of the land in the city, and therefore, the process of amending the Basic Urban Plan was initiated. The planning area of the BUP is 1053 ha. [6] Graphic appendices from this plan have not been found. The data for the plan 
and the size of the urban area are taken from the documentation base of the Basic Urban Plan from 1986.

"Later on the boundary of the building land was expanded on the basis of the Law Amending the Law on the Determination of Building Land in Certain Cities and City-like Settlements, such as Bitola, Prilep, Struga, Sveti Nikole, Dzumajlija, Probishtip, Demir Hisar and Kumanovo (Official Gazette of FRM no. 23 dated 20.06.1975). These new areas for building lands entered into practical use / application on 28.06.1975. "[1]

\section{Basic Urban Plan - Amendments, 1986}

With the rapid population growth of Kumanovo, the urban problems were constantly increasing, so that at the beginning of the 1980s, there was a need for revision of the processes in urban planning and organization of the city. In order to perceive all aspects relevant to the existing situation and determine the development of the city, a complex systematic analytical approach was elaborated with a development of a spatial plan of the city and its territory. The legislative framework for adopting the plan is defined by the 1978 Law on Spatial and Urban Planning, which Siljanoska classifies in the third period of legislation or "the period of enlarging the control instruments important for shaping the city space" [14], while Korobar includes it in a period characterized as "an adaptation of the urban activity in a situation of stagnant social development". [10]

Following the demographic trends, the spatial plan stipulates an increase of the population in the municipality of Kumanovo, with a projection that in 2000 it will have 160,000 inhabitants, of which $91,700(60 \%)$ will be in the city itself (the data refer to the territory of the then municipality of Kumanovo, which included today's municipalities of Kumanovo, Lipkovo and Staro Nagorichane).

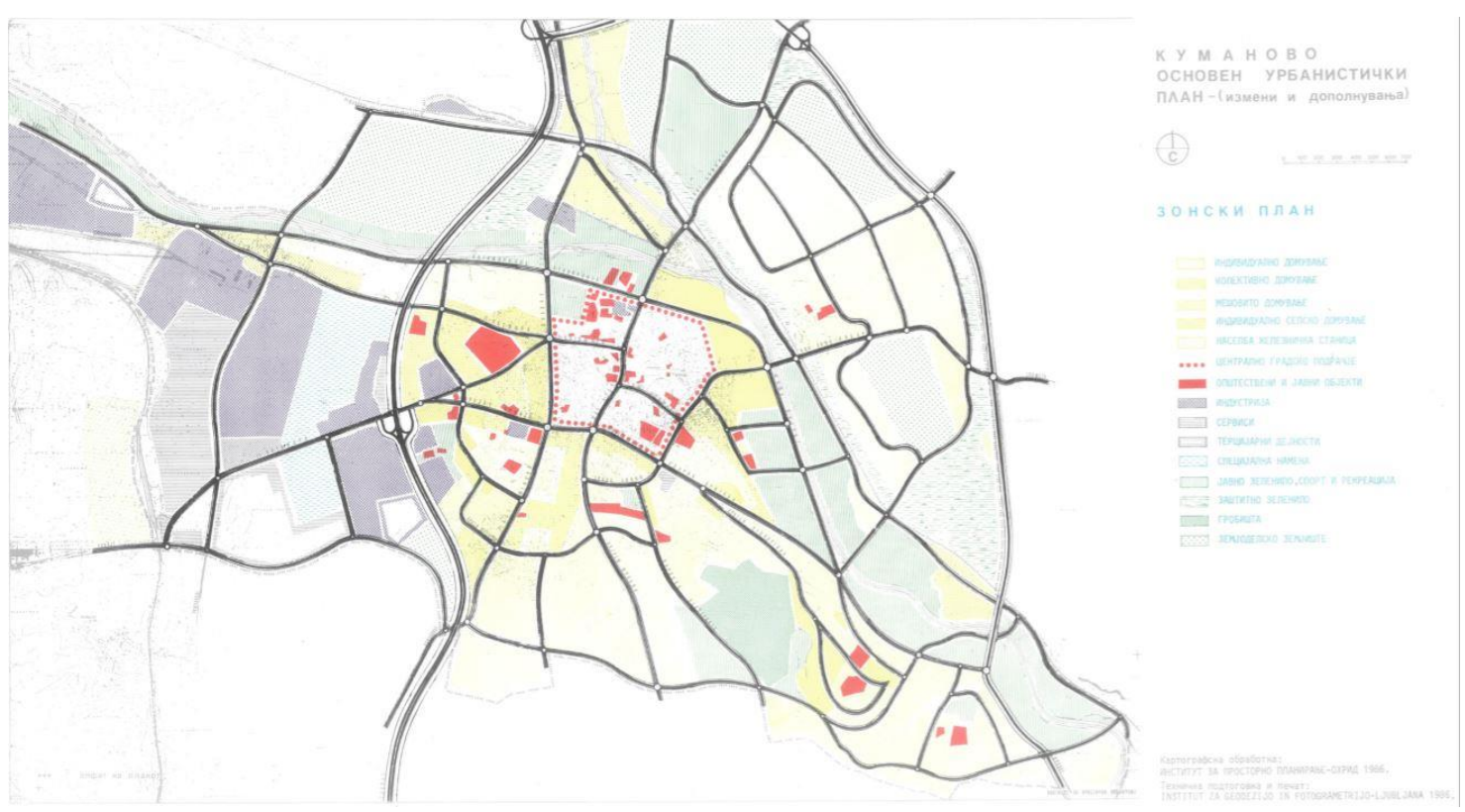

Figure 7. Basic Urban Plan - Amendments from 1986. Graphic appendix of the zone plan, source: Municipality of Kumanovo [8]

The urban area of the plan covers an area of 1823.2 ha. The amendments to the Basic Urban Plan bring about development directions based on analyzes from the spatial plan. A state of unjustified urban expansion of the city zones was established, in conditions of 
low level of rationality in the utilization of space (gross population density per area 38.62 inhabitants / ha). The city is undergoing a process of emphasized de-agrarization, which has a strong influence on suburban settlements, which, in turn, are constantly growing with a rapidly increasing number of inhabitants, thus, transforming into new urban settlements (Dolno Konjare, Bedinje and Proevce).

As a result of the established situation, the Kumanovo Urban Development Plan in 1986 set the following basic goals:

- optimization of the size, structure and functions of the city organism;

- appropriate spatial dispersion of the housing, working and recreational areas, with maximum preservation of the quality of life and rational use of space;

- determining the optimal housing standard;

- planning optimal solutions for infra and supra structures;

- creation of a system of green park areas and protection and improvement of the environment.

The spatial plan treats the city of Kumanovo as one of the poles of development in the Republic, which should carry the role of a development generator in the KumanovoPalanka zone (Kumanovo, Kratovo, Kriva Palanka) all in conjunction with Skopje, as the center of social life in the wider region of the Republic of Macedonia and beyond. [18] The plan places particular emphasis on industrialization, which is growing and it is expected that by the end of the planning period in 2000, the number of job vacancies will increase to 19,700 , i.e. by $73 \%$ in relation to the beginning of the planning period in 1986. The industry in Kumanovo is concentrated on the west side, well situated in terms of natural features and infrastructure. Due to the high degree of utilization of space in the industrialization process, new industry zones are to be created in the south-eastern region, beside the river Pchinja and the Kumanovska Reka.

In the organization and functioning of the city, the existing transit traffic is a permanent factor of influence. Of greatest importance is the A2 Skopje-Belgrade highway as part of corridor 10 with international significance, then the main road Kumanovo-Kriva Palanka, part of corridor 8, also of international significance, and the regional road KumanovoSveti Nikole. These transit thoroughfares (roads and railways) cause, to a certain extent, problems in the organization of internal city traffic, and hence in the urban structure of the city. [8]

\section{General Urban Plan from 2002}

The General Urban Plan from 2002 was drawn up as a revision of the planning solution from the Basic Urban Plan. The plan is in accordance with the new Spatial Plan of the Republic of Macedonia. The plan is a development document with indirect application through detailed urban plans, adopted in accordance with the Law on Spatial Planning and Urban Planning from 1996. [7]

The plan covers an urban area of 1886.3 ha, with a planning period of 10 years, i.e. a development projection by 2012 . 


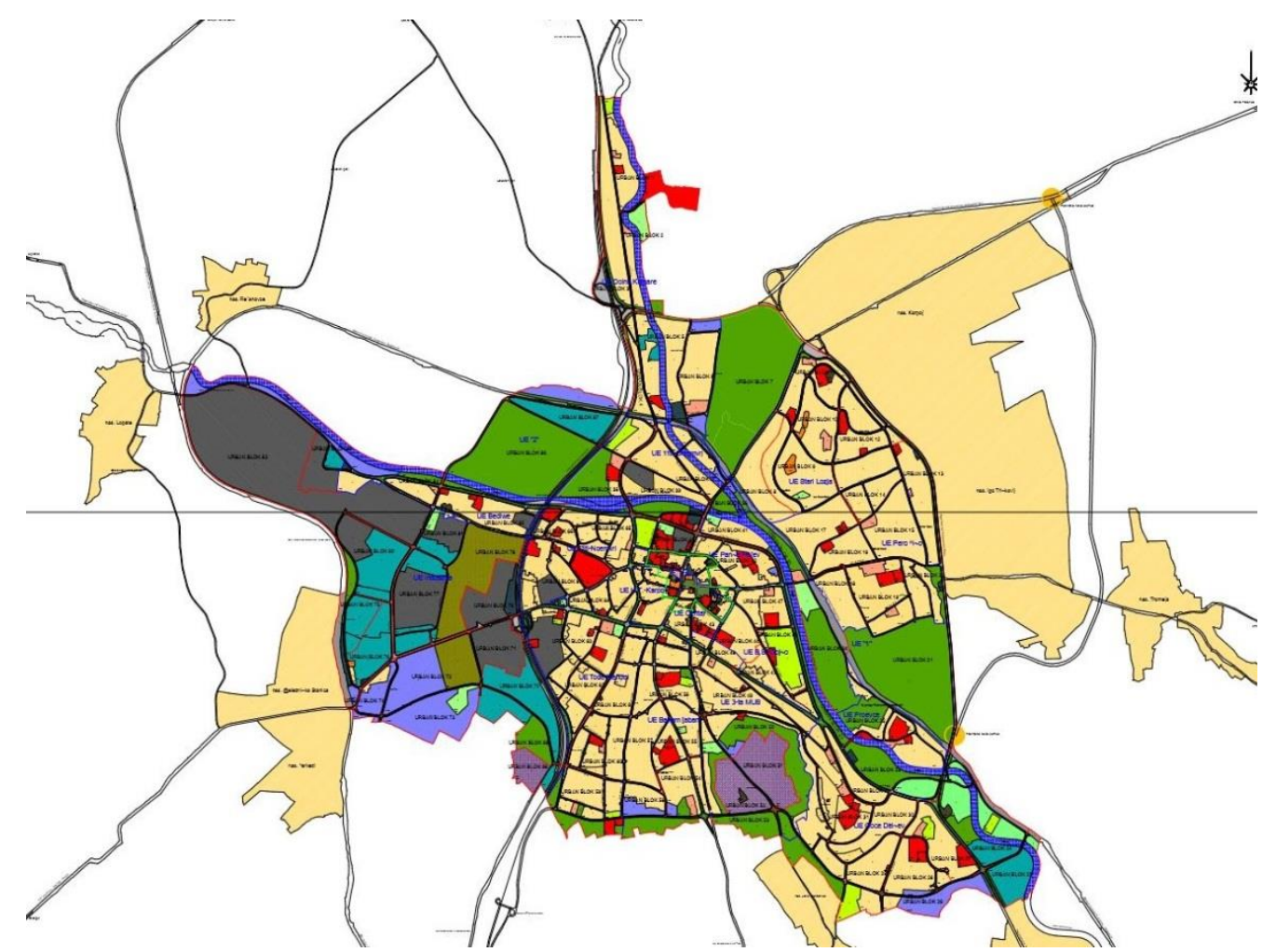

Figure 8. General Urban Plan from 2002. Graphic appendix - synthesis plan, Source: Municipality of Kumanovo [13]

In the Spatial Plan of the Republic of Macedonia, Kumanovo is seen as an important component in the urban system of the country, a centre of wider regional significance, an important node in the system of international and national traffic routes.

The city has penetrated into intense urbanization that is more characterized by quantitative rather than qualitative growth processes in the city's area and its surroundings. According to the 1994 census, the municipality had 94,589 inhabitants, of which 70,416 or $74.4 \%$ lived in the city itself. Since the demographic elements are a basic input for the drafting of the planning development principles, the General Urban Plan provides the basis for the active direction of the demographic flows, so that directions for creating an appropriate city development policy are determined. Namely, there is a tendency to reduce the migration pressure on the city, raise the general cultural and social level of the population, change the economic structure and other important components of the urban life of the population. The demographic analyses predict that, by the end of the planning period in 2012, the total population in the city will be 90,168 . The planning treatment of housing provides for a more rational organization of the urban area. The changes in relation to the previous plan are aimed at increasing the intensity of land use by increasing the population density and the degree of construction. A new relationship between the types of housing is established, which achieves a gross housing density of 47.8 inhabitants / ha.

The urban area covers two zones:

- a housing zone (covering the central city core as a separate spatial-functional unit and urban housing units) and one

- working zone.

Among the created values in the city and its immediate surroundings which appear as possible factors of restricting spatial development are: the high degree of construction on 
the building land with inherited construction fund of poor quality, widespread irregular housing construction that surrounds the city on almost all sides. This type of construction forms part of the city's integral development with two main negative consequences for the city: engagement of land which often has strategic importance for the city's promising development and for the creation of a material fund with a value that cannot be denied, and therefore appears as a restricting factor of the normal planning development. A qualitative factor of spatial development is the great area the city has already occupied. The current monocentric model of the city limits the possibilities for expansion of the city center, restricting its capacities and possibilities for it to develop along with the growing needs of the city.

Overcoming the situation is required within the framework of the decision for balanced development of the city, thus envisaging decentralization of public functions through the introduction of a system of centres. In addition to the city centre, which is at the highest level, it is planned to develop larger local centres and to complete additional contents in the urban units, which, from a methodological point of view, is based on the theory of the Center for Development in Regional Planning. "These centres have three functions: a service centre function, an innovation centre function and a centre for encouraging development, a function of a social integration point." [17]

The industrial zone has a favorable position in terms of segregation from the housing zone, the wind rose, as well as in terms of access to traffic and infrastructure corridors. There is a collision at the downstream position of the Kumanovska River because this causes pollution of the river currents.

Among the factors that limit and hinder the development of the city are certainly the major infrastructure traffic systems of international and national character that pass into the city or its immediate surroundings. Of great significance is the planning project for the flowing Vardar River, which would open a waterway connecting with the Aegean Sea through Vardar, Morava, Danube, Main-Rhine-Baltic Sea, i.e. it provides a connection with the European Network of Channels. The possibility of using these roads for transit and transport would have a great economic effect for our country, and, of course, for Kumanovo, given its location. However, the real assumptions are that it is difficult for this project to be realized in the planning period covered with this plan (in today's planning vision this project is dismissed).

In the urban image, the lack of green park areas is clearly expressed, both in terms of size and in terms of inadequate distribution and connection within the urban structure of the city. The average area of greenery per inhabitant is $9 \mathrm{~m} 2$ (which is a very low average if the number of inhabitants and the size of the city are taken into account). The plan of 2002 stipulates the increase of green park areas with new sports and recreational belts along the rivers, protective greenery, avenues of trees along the streets, etc. In the period until 2012, it is planned that the green areas will be increased to $314.10 \mathrm{ha}$, or $34.83 \mathrm{~m} 2$ / inhabitant, which would mean almost fourfold increase in relation to the existing situation. For the creation and advancement of the ecologically healthy environment of the city, the concept of future development provides for an organized greenery system as the only complete vegetation system within the city-region. [13]

\section{ANALYSIS OF THE URBAN EXPANSION}

The development line of the territorial expansion of Kumanovo reflects the aggregate response of several variables. In the wide range of factors of influence, the dominant position is taken by the socio-political environment with a pronounced dynamics of 
change, the role of the city in the administrative-economic-functional context and its significance at the level of a certain territory, the legislative framework, the planning approach, the existing structure as a construction fund and conditions for implementation of the planning solutions.

\section{Analysis of the fluctuation of the population number}

Considering the demographic analyses in the planning period of the city, the part referring to the fluctuations of the number of the population, we come to the conclusion that when it comes to this issue, the city is going through several periods with different dynamics. In the first, the period between the two World Wars, in which the number of the population showed a constant growth, starting from 15,000 inhabitants, in four decades at a uniform pace, the figure was doubled. The second period is in the interval between the $60 \mathrm{~s}$ and $80 \mathrm{~s}$ of the last century, when population number had been rapidly increasing, with twice stronger dynamics compared to the previous forty years, with a population of 30,000 doubling over a period of only two decades. By the next period, there was a different trend in the fluctuation of the number of population. For the first time, in the analysis from 1991, the number of inhabitants declined to 52,204 (but this is not a realistic picture, because the Albanian population refused to take part in this census), and in the next period the population was again growing, so that in 2002, the number of inhabitants was 70,842 .

Table 1. Cross-section of the number of population.

\begin{tabular}{|l|l|l|l|l|l|l|l|l|l|}
\hline year & 1900 & 1921 & 1941 & 1953 & 1961 & 1971 & 1981 & 1991 & 2002 \\
\hline $\begin{array}{l}\text { number of } \\
\text { population }\end{array}$ & 14.530 & 14.372 & 21.110 & 23.339 & 30.845 & 46.363 & 60.842 & 52.204 & 70.842 \\
\hline$\%$ & & $0.011 \downarrow$ & $46 \uparrow$ & $10.56 \uparrow$ & $32,1 \uparrow$ & $50,3 \uparrow$ & $31.2 \uparrow$ & $14,2 \downarrow$ & $35,7 \uparrow$ \\
\hline
\end{tabular}

Sources: SSO of the Republic of Macedonia (1948-2002 and 2016), [8] [12] [13]

The data above show neither the BUP's nor the GUP's predictions for the planned number of population by the end of the planning periods were not realized. The BUP predicted a population of 80,924 for 1991 , but according to the 1994 census, there were 65,233 inhabitants. With the GUP projections, it was predicted that in 2001 the population would be 97.572 but the 2002 census registered 70.842 inhabitants. These comparative analyzes indicate that the prediction for the increase in the number of inhabitants was not realized as a result of the calm tendency of the large population growth rate in the period 19611981, reflecting a great mechanical influx and a high increase in a part of the population. The emigration wave towards the Western European countries also has an effect on this process. [4][6][8][9][13]

\section{Analysis of the territorial expansion of the city}

The relationships that the city organism as a conglomerate has with its environment are complex. The developed city is an incentive for its own development, but also for the development of its surroundings and vice versa. Of particular interest is the gravitational area on which the influence of the social, economic, and other functions that are carried out in the city is felt. The size of the gravitational area directly depends on the concentration of economic and non-economic facilities and activities in the city. Because of this, Skopje with its gravitational field covers the whole country, and Kumanovo, which is in the vicinity of Skopje $(36 \mathrm{~km})$, builds on the created axis of influence, and its position is a prerequisite for synchronized and complementary development of these two centers. The favorable geographical location, the centrality in relation to the 
municipalities east of the city: Kriva Palanka and Kratovo, as well as Rankovce, Staro Nagorichane and Lipkovo, enabled it to develop into a higher-rank centre, as a gravitational zone in a larger area of the territory of north and northeast Macedonia. [4] Hereby, the concept of pole growth can be seen, where the pole appears as the centre of a polarized economic area. In this setting, the pole, as a hotspot, represents an instrument for progress and development. [17]

The analysis of the territorial expansion of the city is made with the help of a method of comparing the surfaces of urban areas of the urban plans and adopted decisions and laws. The obtained measurements are plan-by-plan and integrally discussed. [1] [4] [5] [6] [8] [13]

Table 2. Preview of surfaces of urban areas of urban plans.

\begin{tabular}{|c|c|c|c|c|c|c|}
\hline 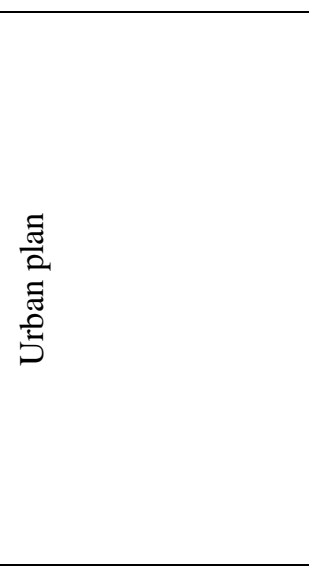 & 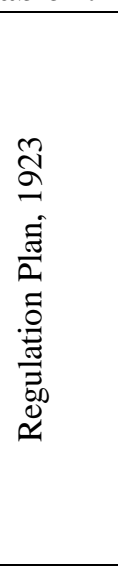 & 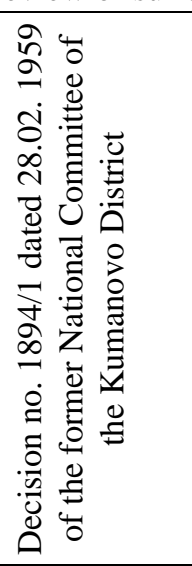 & 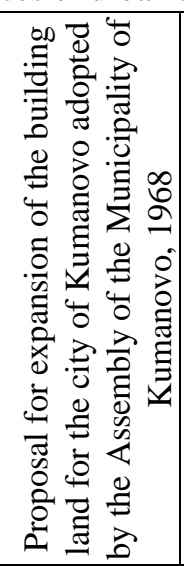 & 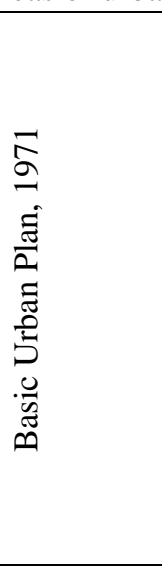 & 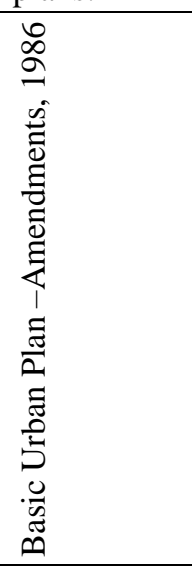 & 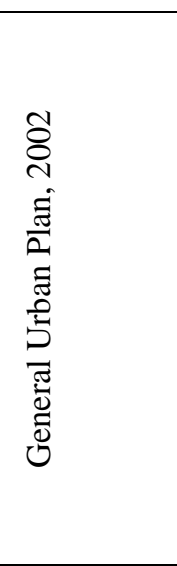 \\
\hline surface area (ha) & 283,17 & 516 & 752 & 1.053 & $1.823,2$ & $1.886,3$ \\
\hline surface increase (ha) & & $232,8(82 \%)$ & $236(46 \%)$ & $301(40 \%)$ & $770,2(73 \%)$ & $63,1(3,4 \%)$ \\
\hline
\end{tabular}

Regulation Plan, 1923.

The area of the 1923 Regulation Plan is 283.17 ha and it is a reflection of the existing situation of the urban web in that period. [4]

Decision no. 1894/1 dated 28.02.1959 of the former National Committee of the Kumanovo District

The 1959 Decision stipulates an increase in the city's area by $232.8 \%$ in relation to the area of the 1923 Plan. [1]

Proposal for expansion of the building land for the city of Kumanovo submitted by the Council for Communal Affairs and Urban Planning of Kumanovo, and adopted by the Assembly of the Municipality of Kumanovo

The next expansion of the city's boundaries is made with the Proposal of the Council for Communal Affairs and Urban Planning which stipulates an increase of 236 ha in relation to the previous decision, which is an increase of $46 \%$. [1]

Basic Urban Plan, 1971.

The Basic Urban Plan for Kumanovo from 1971 is more of a strategic document, with a planning period until 1981. There are not graphic appendices from this plan in the archives of the municipality of Kumanovo. The information on the boundaries provided for by this plan, that is, the size of the planning area, has been taken from the documentation base of the General Urban Plan from 2002, and it is 1,053ha. The plan 
stipulates an increase in the territory by 769.89 ha (representing $272 \%$ of the area), or an increase of 3.7 times the current situation. [6]

Basic Urban Plan - Amendments, 1986

The amendments of the Basic Urban Plan from 1986 follow the planning concept of the previous plan from 1971 and they make a revision of the planning solution with respect to the current situation. Regarding the planning area, it stipulates an increase of the boundaries of the BUP by 770.2 ha. Compared with the plan area from the previous plan, the impact of the population growth rate in this period and the great migration pressure are evident. Because of this, the planner made the development projections for an area which is $73 \%$ larger than the area of the current plan in that period. The boundaries from the plan include suburban settlements, which become serious groups with a population of about 5,000 inhabitants. In addition to expanding the housing zone, the plan stipulates an additional industry development zone on the southeast side of the city. [8]

General Urban Plan, 2002

The planning area of the General Urban Plan from 2002 follows the situation of the previous plan and makes minor changes regarding the territorial position of the boundaries of the city. The subject of analysis in the process of drafting the plan is the situation of irrational land use, with small population density, and unjustifiability of the utilized land, especially of fertile agricultural areas. Because of this, the plan revises the boundaries of the BUP and stipulates a very small increase in the area by $3.4 \%$, i.e. it is mainly dedicated to adapting the current situation.

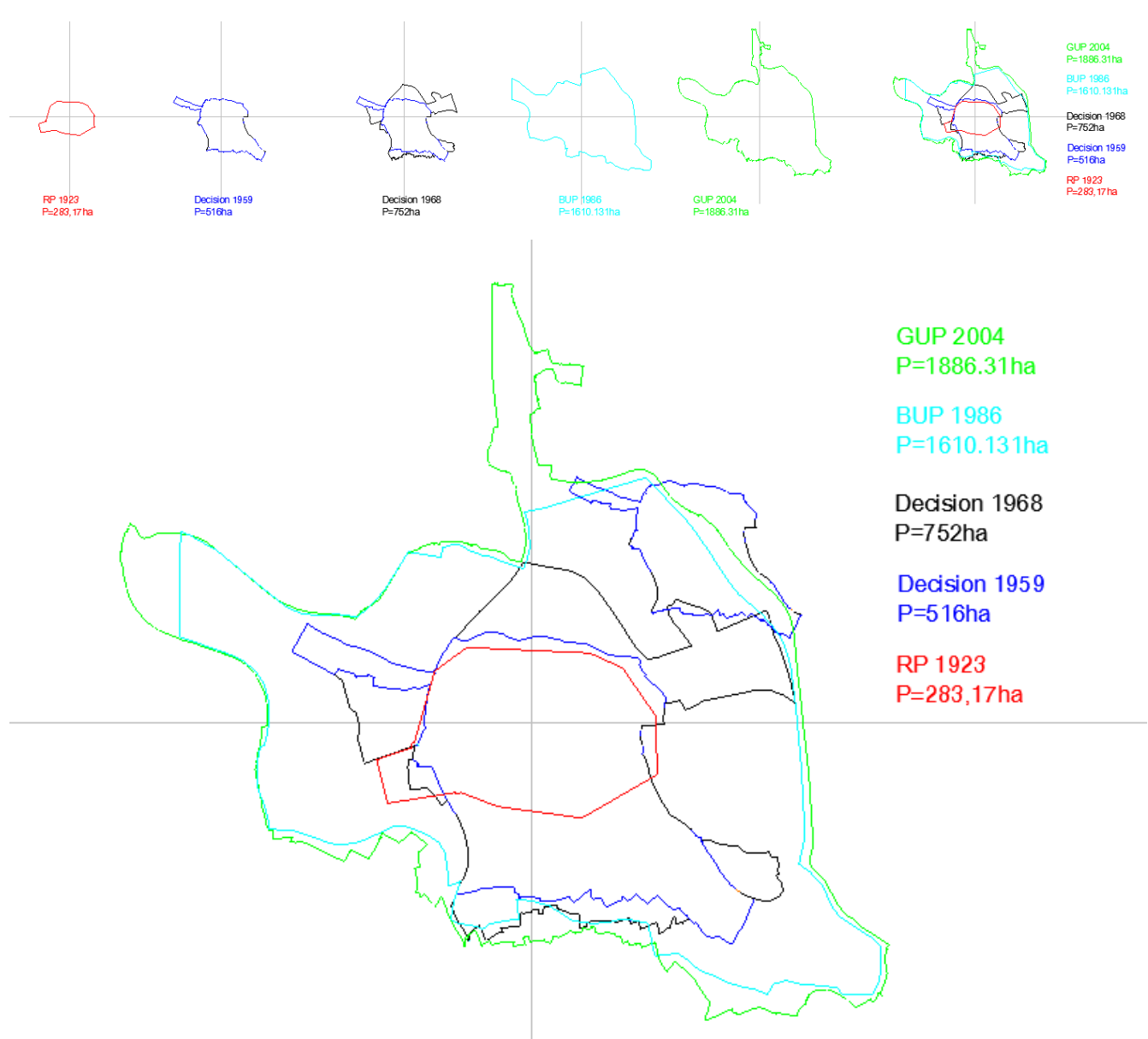

Figure 9. Planning areas of adopted plans and decisions. Source: author 
The following graphic display represents an overlap of the planning areas of all urban plans, for a clearer understanding of the boundaries of the spatial expansion of the city. [13]

\section{CONCLUSION}

Having in mind all elaborations, it can be perceived that the development line of the city of Kumanovo, as a result of the planned treatment, begins in 1923, when a city that follows a European model is planned on the current surface of about 283.17 ha. With the Decision of the former National Commitee of the Kumanovo District from 1959, the boundaries of the city's building land are set at $516 \mathrm{ha}$, and then increased to 752 ha. The development continues along with the next plan in 1971, which stipulates an urban area of about 1,053 ha. During this period, a large increase in the city's planning boundaries is planned, or about 3.7 times compared to the first plan. The tendency of the large expansion of the urban area of the city is also strongly emphasized in the 1986 plan, entitled Basic Urban Plan - Amendments, 1986 which stipulates an urban area of 1,823.2 ha, which represents a $73 \%$ increase in the city's boundaries from the previous plan. This situation is a direct consequence of the strong manifestation of illegally constructed objects in the period of the previous two decades. The growth line of the planning areas reaches its culmination with this plan, and in the next it demonstrates a different trend. With the 2002 General Urban Plan, which is still valid, the boundaries of the city's area are almost unchanged, i.e. they have little modifications in order to align with the existing situation, which is an increase of 3.4\% compared to the previous plan. This means that with the panning development of the city of Kumanovo during a time span of almost 100 years, starting from a present situation of 283 ha in 1923, has reached a situation of 1,886.3 ha planned urban area. The city's area during this period of analysis stipulates a planning increase of the city's boundaries by more than 6.7 times. However, this is a quantitative indicator. What is worrying is the qualitative aspect of the urban web. The illegal construction of objects, which has become a phenomenon, in the period covering the last three to four decades, determined the development not only of Kumanovo, but of the whole country. The consequences of this aggressive rampage, mostly at the expense of the public interest, led the city to a certain level of disfiguration.

These figures, presenting the high rate of growth in the boundaries of Kumanovo, covering its territorial expansion, and creating a qualitative regression in space, raise an inevitable question about the politics of sustainable development, rational use of the land and, of course, protection of the agricultural land and forests. Taking the biological capacity into account, it is estimated that the ecological rate of exhaustion is two to three times higher than the natural capacity. Due to the complex structure involving different segments and their interrelations, there is a need of all-inclusive analysis. In this way, we can obtain an integral representation of the occurrence and its meaning in general. The research has to provide the mutual relations, the conflict points and the negative effects of the urban expansion of the city web, at the expense of the elements for sustainable development and rational land use, protection of agricultural land and forests. When determining the proper program-spatial matrix as a tool for spatial planning, apart from all aspects of the existing situation, the inventory, the process of legalization of illegally constructed objects, the relations in the urban web, the relations between the urban and rural sections, the needs, the spheres of interest, the possibilities for alternative and multipurpose use, as well as the conflict points in using the land, the developing line should be based on the strategic theses of the European Union for spatial planning which 
are mainly oriented towards polycentric and balanced spatial development, integration of the urban and rural environments, territorial integration in the international functional regions, providing competition in regions based on strong local economies, improving communication infrastructure between the population, the community and the economy. This can be done if all aspects of protecting and enhancing the environment and the cultural goods are taken into account. [1] [4] [6] [8] [9] [13] [15] [16]

\section{REFERENCES}

[1] Antevski, N. "Analyses for the Purpose of Legalization of Illegally Constructed Objects within and out of Building Land", Master thesis. Skopje, Ss. Cyril and Methodius University, Faculty of Civil Engineering, Chair of Geodesy, 2001. (Translated from the original: Антевски,Н. „Анализи за легализација на бесправно изградени објекти во градежен и надвор од градежен реон“, магистерски труд. Скопје, Универзитет “Кирил и Методиј”, Градежен факултет, катедра за геодезија, 2001.)

[2] Government of the Republic of Macedonia. Decision on determining the nomenclature of territorial units for statistics - NUTS no. 19-7957/1, 26 December 2010 "Official Gazette of the Republic of Macedonia" issue 158/2007 I 10/2014. (Translated from the original: Влада на РМ. Одлука за утврдување на номенклатура на територијални единици за статистика - НTЕС, бр. 19-7957/1, 26 декември 2010 „Службен весник на Република Македонија" бр. 158 /2007 I 10/2014.)

[3] Daskalovski V., Markoski, B. (1996) "Economic-functional classification of the settlements in the Republic of Macedonia", Geographic observations, Macedonian Geographical Society, Skopje (Translated from the original: Даскаловски В.,Маркоски Б. (1996) Економско функционална класификација на населбите во Република Македонија, Географски разгледи, Македонско географско друштво, Скопје)

[4] Dushan Mirosavljevikj. Regulation Plan for Kumanovo. Kumanovo, 1923. (Translated from the original: Душан Миросављевиќ. Регулационен план на Куманово. Куманово, 1923.)

[5] State Statistical Office. Statistics review: Population and social statistics - ISSN 1409-8997 ESTIMATION of the population on 30.06.2015 and 31.12.2015 by gender and age, p.54. Skopje, 2016. (Translated from the original: Државен завод за статистика. Статистички преглед: Население и социјални статистики - ISSN 1409-8997 ПРОЦЕНИ на населението на 30.06.2015 и 31.12.2015 според полот и возраста, стр. 54. Скопје, 2016.)

[6] Institute for Urban Planning and Architecture of the City of Skopje. Basic Urban Plan for the City of Kumanovo. Kumanovo: Assembly of the Municipality of Kumanovo, 1973. (Translated from the original: Завод за урбанизам и архитектура на град Скопје. Основен урбанистички план на град Куманово. Куманово: Собрание на општина Куманово, 1973.)

[7] Law on Spatial and Urban Planning. Official Gazette of the Republic of Macedonia: issue 4/1996, 51/2005, 199/2014. (Translated from the original: Закон за просторно и урбанистичко планирање. Службен весник на Република Македонија: бр. 4/1996, 51/2005, 199/2014.)

[8] Institute for Spatial Planning - Ohrid. Basic Urban Plan for the City of Kumanovo Amendments. Kumanovo: Assembly of the Municipality of Kumanovo, 1986. (Translated from the original: Институт за просторно планирање-Охрид. Основен урбанистички план на град Куманово-измени и дополнувања. Куманово: Собрание на општина Куманово, 1986.)

[9] Institute for Spatial Planning - Ohrid. Spatial Plan for the Municipality of Kumanovo. Kumanovo: Assembly of the Municipality of Kumanovo, 1986. (Translated from the original: Институт за просторно планирање-Охрид. Просторен план на општина Куманово. Куманово: Собрание на општина Куманово, 1986.)

[10] Korobar, V.P. "Urban Planning in Macedonia in the last fifty years". Jubilee Proceedings 50 years of the Faculty of Architecture. 1999:90-94. (Translated from the original: Коробар,В.П. 
„Урбанистичкото планирање во Македонија во последниве педесет години“. Јубилеен зборник 50 години Архитектонски факултет. 1999: 90-94)

[11] Masevski, D. “Going back to continuity”. Roots. 27 (2008): 4209-4211. (Translated from the original: Масевски, Д. „Враќање кон континуитетот“. Корени. 27 (2008): 4209-4211.)

[12] Masevski, D. "Kumanovo time in its times" fourth amended edition, Kumanovo: Paradigm, 2018. (Translated from the original: Масевски, Д. „Куманово време во неговите времиња“ четврто дополнето издание, Куманово: Парадигма, 2018.)

[13] Prostor DOO Kumanovo. General Urban Plan for Kumanovo. Kumanovo: Municipality of Kumanovo, 2002. (Translated from the original: Простор доо Куманово. Генерален урбанистички план на Куманово. Куманово: Општина Куманово, 2002.)

[14] Siljanoska, J. (2001): Planning aspects of shaping the city space, Phd dissertation, University of Ss. Cyril and Methodius, Faculty of Architecture, Skopje. (Translated from the original: Сиљаноска, J. „Планерските аспекти на обликувањето на градскиот простор“, докторска дисертација. Скопје, Универзитет “Кирил и Методиј”, Архитектонски факултет, 2001.)

[15] Council of the European Union. Territorial agenda of the European Union 2020: Towards an inclusive, smart and sustainable Europe of diverse regions. Agreed at the Informal Ministerial Meeting of Ministers responsible for Spatial Planning and Territorial Development, Gödöllö, Hungary 19 May 2011. http://ec.europa.eu/regional_policy/sources/policy/what/territorialcohesion/territorial_state_and_perspective_2011.pdf

[16] Odzaklieska H., Markoski B., Dimitrovska O., Milevski I. Basic methodological postulates for determining ecological footprint in Republic of Macedonia, Proceedings of the 5th Congress of the Ecologists of Macedonia, with international participation, (Ohrid, 19th-22nd October 2016), Special issues of the Macedonian Ecological Society 13, pp. 135-139, Skopje. 2017. ISBN13 978-9989-648-37-3, Original scientific article, available online at: www.mes.org.mk

[17] Vresk M. “Grad u regionalnom i urbanom planiranju”. Zagreb: Školska knjiga, 1990.

[18] https://mk.wikipedia.org/wiki/Куманово 